\title{
POTENSI EKONOMI LIMBAH TANDAN KOSONG KELAPA SAWIT DAN DEDAK PADI SEBAGAI MEDIA TUMBUH MISELIUM JAMUR TIRAM PUTIH (Pleurotus ostreatus)
}

\section{(ECONOMIC POTENTIAL FROM WASTE OF PALM OIL BUNCH AND RICE BRAN AS A GROWTH MEDIA OF WHITE OYSTER MUSHROOM (Pleurotus ostreatus))}

\author{
Umrah $^{1^{*}}$, Lina Mahardiana ${ }^{2}$, Meryany Ananda ${ }^{1}$, Eny Yuniati ${ }^{1}$, Mutmah Inna ${ }^{1}$ \\ 1Jurusan Biologi, Fakultas Matematika dan IImu Pengetahuan Alam, Universitas Tadulako, Jalan Raya Soekarno- \\ Hatta, Tondo, Palu, 94117, Central Sulawesi, Indonesia. \\ ${ }^{2}$ Fakultas Ekonomi, Universitas Tadulako, Jalan Raya Soekarno-Hatta, Tondo, Palu, 94117, Central Sulawesi, \\ Indonesia.
}

Keywords:

White Oyster Mushroom, Palm Oil Bunch, Rice Bran

Kata Kunci:

Jamur Tiram Putih, Limbah

Tandan Kosong Kelapa

Sawit, Dedak Padi

\begin{abstract}
This research was conducted on waste of palm oil bunch and rice bran which are a source of high economic value nutrients that can be used as a growth media for white oyster mushroom (Pleurotus ostreatus). The objectives of the study were (1) determine the growth in mycelium of white oyster mushroom ( $P$. ostreatus) on the waste of palm oil bunch and rice bran; (2) determine the characteristics of white oyster mushroom with different substrate. This study was conducted in a completely randomized design (CRD) consisting of seven treatments and three repetitions. The composition of the treatment were P1 $(50 \%$ : 50\%), P2 (45\%: 55\%), P3 (40\%: 60\%), P4 (35\%: 65\%). P5 (30\%: $70 \%$ ), P6 (25\% : 75\%), P7 (sawdust 70\%, rice bran 20\%, corn flour $10 \%)$. The results showed that the fastest mycelium growth rate was P1 $(89 \mathrm{~mm})$ and the lowest was P5 $(80 \mathrm{~mm})$. The highest number of colonies was P5 $\left(1.4 \times 10^{12} \mathrm{CFU} / \mathrm{g}\right)$ and the lowest was P4 $\left(0.4 \times 10^{12}\right.$ $\mathrm{CFU} / \mathrm{g}$ ). The fastest incubation time was P4 (28 days) and the lowest was P7 (33 days).

\section{ABSTRAK}

Penelitian ini perlu di lakukan karena pada limbah tandan kosong kelapa sawit dan dedak padi merupakan sumber nutrisi yang bernilai ekonomi tinggi yang dapat dimanfaatkan sebagai media pertumbuhan jamur tiram putih (Pleurotus ostreatus). Tujuan penelitian ini adalah (1) mengetahui pertumbuhan miselium jamur tiram putih ( $P$. ostreatus) pada substrat limbah tandan kosong kelapa sawit dan dedak padi; (2) mengetahui karakteristik pertumbuhan jamur tiram putih ( $P$. ostreatus) pada perlakuan jenis substrat yang berbeda. Penelitian ini telah di lakukan dalam rancangan acak lengkap (RAL) yang terdiri tujuh perlakuan dan tiga kali pengulangan. Susunan perlakuan merupakan perbandingan antara tandan kosong kelapa sawit : dedak padi, yakni P1 (50\%: 50\%), P2 (45\% : 55\%), P3 (40\%: $60 \%)$, P4 (35\%: $65 \%)$. P5 (30\% : 70\%), P6 (25\% : 75\%), P7 (serbuk geragaji 70\%, dedak padi $20 \%$, tepung jagung $10 \%$ ). Adapun hasil penelitian menunjukkan laju pertumbuhan miselium tercepat pada perlakuan P1 yaitu $89 \mathrm{~mm}$ dan terendah pada perlakuan P5 yaitu $80 \mathrm{~mm}$. Jumlah koloni tertinggi pada perlakuan $P 5$ yaitu $1,4 \times 10^{12} \mathrm{CFU} / \mathrm{g}$ dan terendah pada perlakuan P4 yaitu $0,4 \times 10^{12} \mathrm{CFU} / \mathrm{g}$. Waktu inkubasi paling cepat pada perlakuan $\mathrm{P} 4$ yaitu 28 hari dan terendah pada perlakuan $\mathrm{P} 7$ yaitu 33 hari.
\end{abstract}

Corresponding Author : umrah.mangonrang62@gmail.com 


\section{PENDAHULUAN}

Budidaya jamur tiram putih termasuk salah satu program budidaya relatif baru dan masih sangat kurang dikenal dikalangan masyarakat luas. Komoditas jamur khususnya jamur merang mulai diperkenalkan pada tahun 1960-an. Akan tetapi pengembangannya mulai diusahakan secara komersial serta dikenal oleh masyarakat pada tahun 1970-an, sedangkan jamur tiram putih dikenal oleh masyarakat lebih belakangan lagi. Yaitu sejak tahun 1980-an di beberapa kawasan pulau Jawa (Maulana, 2012). Jamur tiram merupakan jamur pangan yang berasal dari kelompok Basidiomycetes, disebut jamur tiram karena tudungnya berbentuk lingkaran seperti cangkang tiram.

Jamur tiram putih (Pleurotus ostreatus) saat ini populer dan digemari oleh masyarakat (Alex, 2011). Nama jamur tiram diambil berdasarkan bentuk tudungnya yang melengkung, lonjong dan membulat menyerupai kerang atau cangkang tiram dengan bagian tepi yang bergelombang. Pada setiap 100 gram jamur tiram mengandung nutrisi dengan kandungan 367 kalori, protein 10,5 - 30,4\%, karbohidrat $56,6 \%$, lemak $1,7-2,2 \%, 314 \mathrm{mg}$ kalsium dan mengandung vitamin. Jamur juga mengandung serat mencapai 7,4 - 24,6\% sehingga baik untuk pencernaan dan cocok untuk para pelaku diet. Selain itu jamur tiram bermanfaat untuk menurunkan kolesterol, sebagai anti bacterial dan anti tumor, sebagai obat penyakit lever, diabetes dan anemia (Purnawanto, 2013).

Media pertumbuhan jamur merupakan aspek penting dalam pembudidayaan jamur tiram. Jamur tiram (Pleurotus ostreatus) adalah organisme dengan kemampuan paling efisien dalam mendegradasi lignin dan selulosa karena mengandung enzim lignocelullytic (Sudirman, 2011).

Jamur ini dapat tumbuh pada limbah tandan kosong kelapa sawit dan dedak padi karena di dalamnya terdapat kandungan selulosa. Limbah tandan kosong kelapa sawit dan dedak padi digunakan sebagai substrat pertumbuhan jamur tiram putih, kandungan dari serbuk tandan kosong kelapa sawit dan dedak padi terdiri dari lignin, selulosa dan hemiselulosa. Ketersedian kedua limbah tersebut sangat banyak dan mudah didapatkan. Kedua limbah tersebut dapat digunakan sebagai media pertumbuhan jamur tiram yang bermanfaat bagi kesehatan tubuh serta mempunyai nilai jual tinggi. Kandungan nutrisi pada tandan kosong kelapa sawit mengandung hara nitrogen $1,5 \%$, pospor $0,5 \%$, kalsium $7,3 \%$ dan magnesium 0,9\% (Alex, 2011). Kandungan nutrisi pada dedak padi mengandung protein 11,3-14,4\%, lemak $15,0-19,7 \%$, serat kasar 7,0-11,4\%, karbohidrat 34,1-52,3\% dan abu 6,6-9,9\% (Ali, 2013). 
Berdasarkan latar belakang masalah yang telah diuraikan di atas maka penelitian ini penting untuk dilakukan dengan tujuan mengetahui karakteristik pertumbuhan miselium jamur tiram putih ( $P$. ostreatus) pada substrat limbah tandan kosong kelapa sawit dan dedak padi.

\section{BAHAN DAN METODE}

\section{Bahan}

Bahan utama yang digunakan dalam penelitian ini adalah limbah tandan kosong kelapa sawit dan dedak padi. Kedua bahan tersebut merupakan limbah hasil pertanian yang relatif terbuang, karena tidak bermanfaat.

\section{Metode}

\section{Persiapan Media Pertumbuhan Jamur} Tiram Putih

Limbah tandan kosong kelapa sawit yang digunakan berasal dari pabrik pengolahan kelapa swit dan limbah dedak padi berasal dari salah satu kebun petani yang berada di desa Parabu. Kedua limbah diletakkan di tempat yang telah disiapkan untuk kemudian dicacah menggunakan parang dan kapak.

Setelah dicacah, kedua limbah tersebut dikeringkan di atas terpal selama 3-4 hari. Setelah dikeringkan, limbah kemudian ditimbang sebanyak $10 \mathrm{~kg}$ untuk digiling menggunakan alat penggilingan kelapa yang berukuran sedang. Setelah itu, limbah digiling kembali menggunakan penggiling tepung dengan ukuran saringan $3 \mathrm{~mm}$.

\section{Formulasi Perlakuan}

Penelitian ini didesain dengan rancangan acak lengkap (RAL), terdiri tujuh perlakuan dan tiga kali pengulangan. Susunan perlakuan sebagai berikut:

- $\mathrm{P} 1=$ tandan kosong kelapa sawit $50 \%+$ dedak padi $50 \%$

- $\mathrm{P} 2$ = tandan kosong kelapa sawit $45 \%+$ dedak padi $55 \%$

- $\mathrm{P} 3=$ tandan kosong kelapa sawit $40 \%+$ dedak padi $60 \%$

- $\mathrm{P} 4$ = tandan kosong kelapa sawit $35 \%+$ dedak padi $65 \%$

- $\mathrm{P} 5$ = tandan kosong kelapa sawit $30 \%+$ dedak padi $70 \%$

- $\mathrm{P} 6$ = tanda kosong kelapa sawit $25 \%+$ dedak padi $75 \%$

- $\quad \mathrm{P} 7=$ serbuk geragaji $70 \%$ + dedak padi $20 \%+$ tepung jagung $10 \%$ (kontrol positif).

\section{Parameter Pengamatan}

Parameter pengamatan pada penelitian ini adalah karakterisitik mikroskopik hifa, karakteristik pertumbuhan miselium, laju pertumbuhan miselium dan masa inkubasi sampai miselium memenuhi botol kultur. Selanjutnya data hasil pengamatan secara kuantitatif akan dianalisis menggunakan Anova one ways dan akan dilanjutkan 
dengan uji "Duncan" bila terjadi perbedaan yang nyata.

\section{HASIL DAN PEMBAHASAN}

\section{Media Pertumbuhan Jamur Tiram Putih}

Media pertumbuhan jamur tiram putih yang digunakan berasal dari limbah tandan kosong kelapa sawit dan dedak padi yang diolah melalui proses pencacahan, pengeringan, penggilingan hingga limbah tersebut berbentuk serbuk media (Gambar 1).

Tandan kosong kelapa sawit memiliki kandungan nutrisi pospor $0,5 \%$, hara nitrogen $1,5 \%$, kalsium $7,3 \%$ dan magnesium 0,9\%. Pada dedak padi memiliki kandungan nutrisi lemak 15,0$19,7 \%$, protein $11,3-14,4 \%$, karbohidrat $34,1-52,3 \%$, serat kasar $7,0-11,4 \%$ dan abu $6,6-9,9 \%$. Kedua limbah ini memiliki komposisi nutrisi yang sangat dibutuhkan dalam pertumuhan jamur tiram putih.

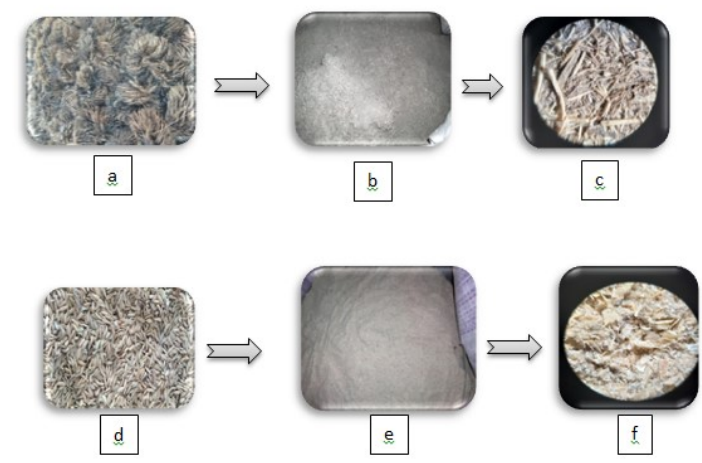

Gambar 1. Media dasar pertumbuhan: (a) Tandan kosong kelapa sawit, (b) Serbuk tandan kosong kelapa sawit, (c) Mikro serbuk tandan kosong kelapa sawit, (d) Padi, (e) Dedak padi, (f) Mikro dedak padi.

\section{Parameter Pengamatan}

- Karakteristik Mikroskopik Miselium

Hasil pengamatan karakteristik mikroskopik miselium jamur tiram putih dapat dilihat pada gambar 2 . Pengamatan mikroskopik dilakukan dengan menggunakan perbesaran 400x.
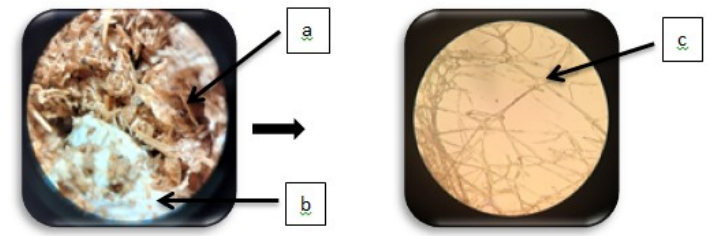

Gambar 2. (a) Media Pertumbuhan, (b) Miselium, (c) Hifa

- Karakteristik

Pertumbuhan Miselium

Hasil pengamatan karakteristik pertumbuhan miselium media pertumbuhan dapat dilihat pada gambar 3. Karakteristik pertumbuhan miselium dinilai berdasarkan kriteria banyaknya pertumbuhan miselium yang memenuhi botol kultur (Tabel 1).

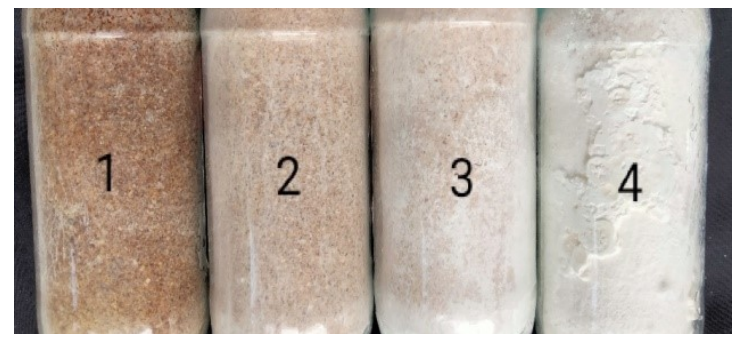

Gambar 3. Karaktristik Pertumbuhan miselium Jamur Tiram Putih pada Botol kultur 
Tabel 1. Kriteria Pertumbuhan Miselium Jamur Tiram Putih pada Botol Kultur

\begin{tabular}{ccc}
\hline Perlakuan & Nilai & Kriteria \\
\hline P1 & 3 & Banyak \\
\hline P2 & 3 & Banyak \\
\hline P3 & 3 & Banyak \\
\hline P4 & 3,5 & Sangat Banyak \\
\hline P5 & 3,5 & Sangat Banyak \\
\hline P6 & 3 & Banyak \\
\hline P7 & 2,5 & Banyak
\end{tabular}

Keterangan:

0 - 1 : Sedikit, $\pm\left(3,5 \times 10^{2}\right)$ CFU/g

$1,1-2$ : Kurang banyak, $\pm\left(4,5 \times 10^{6}\right) \mathrm{CFU} / \mathrm{g}$

$2,1-3:$ Banyak, $\pm\left(9,0 \times 10^{10}\right) \mathrm{CFU} / \mathrm{g}$

3,1- 4 : Sangat banyak, $\pm\left(5,0 \times 10^{11}\right) \mathrm{CFU} / \mathrm{g}$

Perhitungan jumlah koloni dengan menggunakan metode Total Plate Count (TPC. Semua perlakuan menunjukkan hasil jumlah koloni yang berbeda dengan masa inkubasi selama 2x24 jam (Gambar 4).

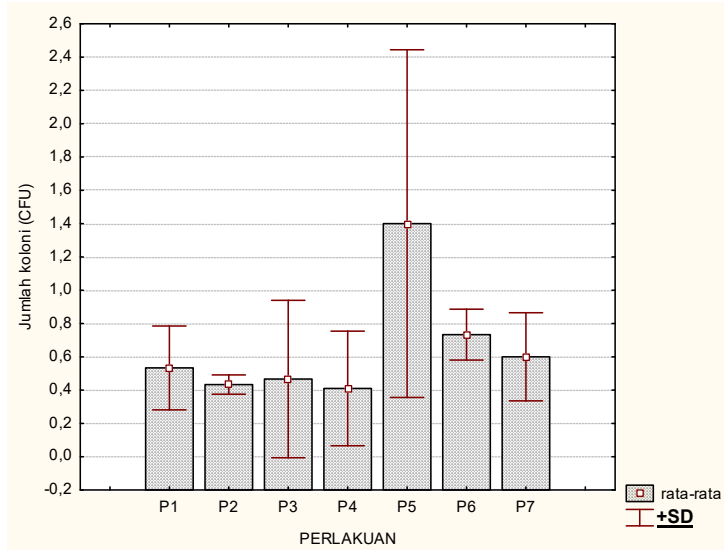

Gambar 4. Rata-rata jumlah koloni pada miselium jamur tiram putih.
- Laju Pertumbuhan Miselium Jamur Tiram Putih

Laju pertumbuhan miselium jamur tiram putih dapat dilihat pada gambar 4 Petumbuhan miselium dimulai dari hari ke-3 sampai hari ke-33 masa inkubasi (Gambar 5).

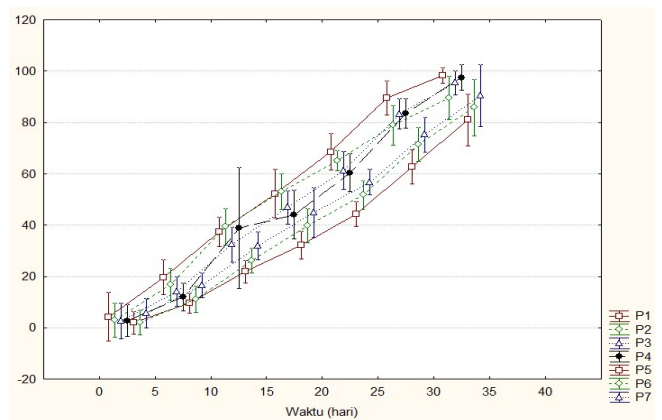

Gambar 5. Hasil pengamatan kurva pertumbuhan miselium jamur tiram putih

Pengamatan laju pertumbuhan miselium pada setiap perlakuan yang dilakukan selama selang waktu 3 hari menunjukkan hasil yang berbeda (Gambar 6).

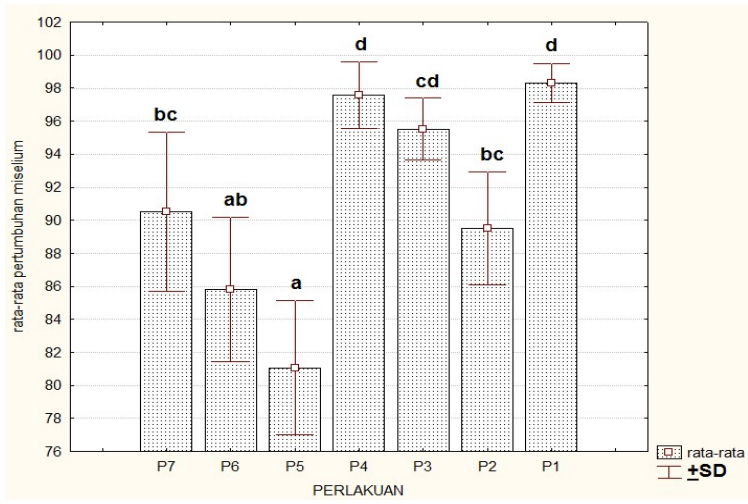

Gambar 6. Rata-rata pertumbuhan miselium pada botol kultur untuk setiap perlakuan umur 33 hari setelah inokulasi. Huruf yang berbeda terdapat pada bar menunjukkan perbedaan yang nyata pada taraf $p<0,05$. 
Pertumbuhan miselium jamur tiram putih pada perlakuan P1 menunjukkan pertumbuhan yang paling cepat $(98 \mathrm{~mm})$. Sedangkan pada perlakuan P5 menunjukkan pertumbuhan yang paling lambat $(85 \mathrm{~mm})$.

\section{- Masa Inkubasi}

Hasil pengamatan masa inkubasi pada setiap perlakuan sampai miselium memenuhi media botol kultur menunjukkan hasil yang berbeda. Masa inkubasi yang dibutuhkan paling lama sampai hari ke-33, setiap perlakuan membutuhkan rata-rata waktu inkubasi yaitu $\mathrm{P} 1=32$ hari, $\mathrm{P} 2=30$ hari, $\mathrm{P} 3=31$ hari, $P 4=28$ hari, $P 5=29$ hari, $P 6=31$ hari, $\mathrm{P} 7=33$ hari (Gambar 7).

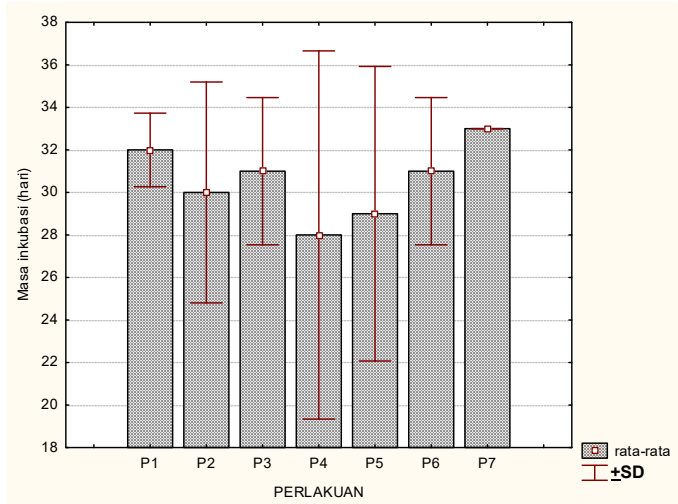

Gambar 7. Rata-rata waktu inkubasi sampai miselium memenuhi botol kultur.

Untuk mendapatkan hasil produksi jamur tiram yang demikian, dapat dikatakan bahwa biaya produksi jamur tiram dengan menggunakan media tanam limbah tandan kosong kelapa sawit lebih rendah, menghasilkan jumlah koloni lebih tinggi, dengan miselium dengan ukuran tubuh buah lebih besar, sehingga jumlah produksinya lebih banyak dan lebih berkualitas, sehingga harga jual hasil produksinya lebih tinggi.

\section{SIMPULAN}

Berdasarkan dari hasil penelitian dapat di simpulkan bahwa:

1. Miselium jamur tiram putih dapat tumbuh dengan baik dan tidak memerlukan waktu yang lama. pada perlakuan P1, P3 dan P4.

2. Miselium jamur tiram putih memiliki karakteristik pertumbuhan yang berbedabeda. Perlakuan P5 menunjukkan karakteristik pertumbuhan miselium paling baik berdasarkan karakteristik pertumbuhan miselium sampai memenuhi botolkultur (sangat banyak) dan jumlah koloni $\left(1,4 \times 10^{12} \mathrm{CFU} / \mathrm{g}\right)$,

\section{UCAPAN TERIMA KASIH}

Terima kasih kepada Direktorat Riset dan Pengabdian Masyarakat, Direktorat Jenderal Penguatan Riset dan Pengembangan Kementerian Riset, Teknologi dan Pendidikan Tinggi, atas dukungannya dalam pelaksanaan kegiatan ini melalui Skema PPUPIK tahun 2021 Universitas Tadulako, sesuai dengan Perjanjian Penugasan Pelaksanaan Program Pengabdian Masyarakat Nomor : 078/SP2H/PPM/DRPM/2021. 


\section{DAFTAR PUSTAKA}

Achmad, J., H, et all. (2010). Karakter Morfologi dan genetik Jamur Tiram (Pleurotus ostreatus). Vol 21 (3): 225231

Agromedia, R. (2010). Bertanam Jamur Konsumsi (Tiram, Kuping, Shiitake, Merang dan Champignon). PT. Agromedia Pustaka. Jakarta.

Akbar, M.R.L., D. M. Suci dan I. Wijayanti. (2017). Evaluasi kualitas pellet pakan itik yang disuplementasi tepung daun mengkudu (Morinda citrifolia) dan disimpan selama 6 minggu. Buletin Makanan Ternak 104(2): 31 - 48.

Alex, M.S. (2011). Meraih Sukses Dengan Budidaya Jamur Tiram, Jamur Merang, dan Jamur Kuping. Penebar Swadaya: Jakarta.

Ali, N., N.M. Tabi, F.A. Zakil, W.N.F.M. Fauzai, O. Hassan. (2013). Yield Peformance And Biological Efficiency Of Empty Fruit Bunch (EFB) And Palm Pressed Fibre (PPF) As Substrates For The Cultivation of Pleurotus ostreatus. Facully of Chemical Engineering. University Teknologi Malaysia. Malaysia: 64 (1): 93-99.

Arung, E. T., Kusuma, I. W., Kim, Y.-U., Shimizu, K., \& Kondo, R. (2012). Antioxidative compounds from leaves of Tahongai (Klienhovia hospita). Journal of wood science, 58(1), 77 80.

Egra, S., Kusuma, I. W., \& Arung, E. T. (2018). Potensi Jamur Tiram Putih (Pleurotus ostreatus) Terhadap Penghambatan Candida albicans dan Propionibacterium acnes. ULIN: Jurnal Hutan Tropis, 2(1).
Fauzi, Y., Widyastuti, Y., Satyawibawa, I., Paeru, R. (2012). Kelapa Sawit. Penebar Swadaya, Jakarta.

Iswahyudi H., Lukmana M., dan Yudha M., (2017). Limbah serabut kelapa sawit sebagai media tanam alternatif bagi jamur tiram puti (Pleurotus osreatus). Jurnal Teknologi Agro - Industri Vol.4 No.1. 2407 - 4624.

Khatun S, MD Ashraduzaman, MR Karim, $F$ Pervin, N Absar \& A Rosma. (2012) - Purification and characterization of peroxidase from Moringa oleifera leaves. Bio Resources 7 (3): 3237-3251.

Kusuma, I. W., Arung, E. T., \& Kim, Y.-u. (2014). Antimicrobial and antioxidant properties of medicinal plants used by the Bentian tribe from Indonesia. Food Science and Human Wellness, 3(3-4), 191-196.

Lin, M., Setiarti Sukotjo, Sidik Marsudi. (2015) - Potential of oil palm empty fruit bunch (EFB) as media for Oyster mushroom, Pleurotus ostreatus cultivation. Procedia Chemistry 16: 427-431.

Maulana, E. (2012). Panen Jamur Tiap Musim (panduan Lengkap Bisnis dan Budidaya Jamur Tiram). Penerbit Andi. Yokyakarta.

Mardiana, S., Ellen, L. P., \& Retno, A.K. (2016). Pengelolaan Limbah Pertanian Dan Perkebunan Sebagai Media Pertumbuhan Jamur Tiram (Pleurotus ostrearus) [Penelitian Hibah Bersaing]. Fakultas Pertanian, Universitas Medan Area, Medan.

Ningtyas, V. A. \& Astuti, L.Y. (2010). Pemanfaatan Tandan Kosong Kelapa Sawit Sisa Media Jamur Merang (Volvariella volvacea) sebagai pupuk organik dengan penambahan aktivator effective microorganism EM4. Skripsi, ITS Library. 
Purnawanto, A. M., O. D. Hajoeningtijas dan P. Utami. (2013). Pengaruh Takaran Bekatul dan Pupuk Anorganik Terhadap Hasil Jamur Tiram Putih (Pleurotus ostreatus). Jurnal Agritech. 23(2):1-14.

Rochman Abdul. (2015). Perbedaan Proporsi Dedak Dalam Media Tanam Terhadap Pertumbuhan Jamur Tiram Putih (Pleurotus florida). Jurnal Agribisnis Fakultas Pertanian Unita Vol. 11 No. 13.

Saskiawan, I., \& Hasanah, N. (2015). Aktivitas antimikroba dan antioksidan senyawa polisakarida jamurtiram putih (Pleurotus ostreatus). Pros Sem Nas Masy Biodiv Indon, 1(5), 1105-1109.

Seswati, R., Nurmiati., dan Periadnadi. (2013). Pengaruh Pengaturan Keasaman Media Serbuk Gergaji Terhadap Pertumbuhan dan Produksi Jamur Tiram Cokelat (Pleurotus cystidiosus ). Jurnal Biologi Universitas Andalas Vol 2(1) : 31-36.

Siregar, H.J. (2010). Pertumbuhan dan Produksi Jamur Merang (Volvariella volvaceae) pada Media Tandan
Kosong Kelapa Sawit dengan Waktu Fermentasi yang Berbeda. Skripsi. Fakultas Pertanian, Universitas Sumatera Utara, Sumatera Utara.

Suwandra, H. (2016). Nilai Tambah Produksi Jamur Tiram (Pleurotus ostreatus) Menggunakan Limbah Tandan Kosong Kelapa sawit (TKKS) dan Serbuk Gergaji. Fakultas Pertanian. Universitas Bengkulu.

Shifriyah, A., K. Badami, \& Suryawati. (2012). Pertumbuhan dan produksi jamur tiram putih (pleurotus ostreatus) pada penambahan dua sumber nutrisi. Jurnal Agrovigor 5(1): 8-13.

Sudirman, L.I, Sutrisna, A., Listiyowati, S., Fadli, L. \& Tarigan, B.A.L.A.M.A.N. (2011). The Potency of Oil Palm Plantation Wastes for Mushroom Production. In Proceedings of the 7th International Conference on Mushroom Biology and Mushroom Products (pp. 383-389). France. 